\title{
Effects of morphology in the nativisation of loanwords: The borrowing of /s/ in Xitsonga
}

\author{
Seunghun J. Lee ${ }^{1}$ \\ Psychology and Linguistics, International Christian University, Tokyo, Japan \\ E-mail: seunghun@icu.ac.jp
}

\begin{abstract}
Madala Crous Hlungwani
MER Mathivha Centre for African Languages, Arts and Culture, University of Venda, South Africa E-mail: Crous.hlungwane@univen.ac.za
\end{abstract}

\begin{abstract}
This article argues that the nativisation of loanwords in Xitsonga results from a pressure from morphology. In Xitsonga, a southern Bantu language, the $/ \mathrm{s} / \mathrm{in} / \mathrm{sC} /$ clusters of English is always realised as $[\mathrm{s}]$ in non-initial positions. This $/ \mathrm{s} /$ is realised with variations when it appears in the initial position: either faithfully with an alveolar fricative [s], or with a palatal fricative [J]. A loanword adaptation experiment confirms that this position-sensitive variation is part of the phonological grammar of a Xitsonga speaker. The adaptation of initial $/ \mathrm{sC} /$ clusters to $[\mathrm{siC}]$ in the nativisation process is argued to result from pressures to incorporate loanwords into the existing noun class system - a case where morphology triggers phonological changes by creating a class 7 noun prefix [ $\mathrm{ji}$ ]. What is remarkable is the non-occurrence of palatalisation in non-initial positions. Since non-initial consonants are not subject to the same morphological pressure, the nativisation process of $/ \mathrm{s} /$ in these positions to $\left[\int\right]$ is blocked.
\end{abstract}

Keywords: loanword phonology, nativisation, loanwords, morphological pressure, phonologymorphology interface, Xitsonga

\section{Introduction}

Patterns in the nativisation of loanwords depend heavily on the phonological grammar of the recipient language (cf. Kang 2011, 2013). There are two major processes that have been proposed to account for the ways in which words are borrowed into other languages. Borrowing through bilingual speakers in a speech community is one way, and the other is borrowing by speakers who introduce words from a language foreign to their own language. The former

\footnotetext{
${ }^{1}$ Corresponding author.
} 
process is called "nativization-through-production", and the latter is "nativization-throughperception" (Calabrese and Wetzels 2009).

Whether the motivation behind nativisation is production or perception, what is constant is that speakers of a recipient language produce a phonologically altered form of a donor language on the surface, when there is a difference in the phonological component of the grammar between the recipient language and the donor language. For example, the absence of a sound of a donor language in the recipient language often results in changes in the original sound in the nativisation process. In Korean, which does not have the labiodental fricative [v] in the sound inventory, 'van' is adapted as '[b]an'. Another example is when the phonotactics of a recipient language do not allow a sequence of sounds from a donor language. In Japanese, where consonant clusters are not allowed, the English word 'desk' is adapted as [desuku] in which the [sk] cluster is separated by the epenthetic vowel [u].

Nativisation processes are often language-specific as well. The interdental fricative [ð] in English is adapted as [d] in Korean and Japanese, but [z] in some varieties of Spanish (cf. Lombardi 2003). When consonant clusters are not allowed in a language, an epenthetic vowel can appear either before the cluster (Bengali [iskul] 'school', [i] before [sk]; Karim 2010: 282) or in the middle of the cluster (Xitsonga [Jikkolo] 'school', [i] within [Jk]).

The major goal of this article is to investigate the nativisation process of English $/ \mathrm{sC} /$ clusters in Xitsonga, a southern Bantu language (S53). A set of examples from Xitsonga shows the phonological adaptation of the $/ \mathrm{s} /$ sound in $/ \mathrm{sC} /$ clusters with variations, as in (1), which is limited to the initial position. The $/ \mathrm{C} / \mathrm{symbol}$ stands for the voiceless stops $/ \mathrm{p} /, / \mathrm{t} /$, or $/ \mathrm{k} /$. The $/ \mathrm{s} /$ sound is realised as a palatal fricative [J] in 'skate' in (1a), but as [s] in 'scat' in (1b). The rest of the words are identical, thus creating a minimal pair in loanwords.
a. [ [jikéti $]^{3}$
'skate'
b. [sikéti]
'scat'

Xitsonga does not allow consonant clusters in general. Thus, a $/ \mathrm{sC} /$ cluster in the donor language (English) is divided by an epenthetic vowel, as it is common that a segment is preserved in the recipient language rather than deleted (cf. Smith 2006). In Xitsonga, the [i] [i] vowel is inserted for illicit /sC/ clusters that are banned in its native grammar. ${ }^{4}$

Although variations exist, nativisation processes in loanword phonology are still systematic, and those processes provide evidence for the understanding of speakers' grammatical competence (Adler 2006: 1025). As such, understanding characteristics of loanword phonology requires a systematic investigation of patterns that fit into specific categories. Naturally occurring loanwords that enter into a grammatical system, however, are less likely to cover every possible pattern that can be utilised to understand the grammar of loanwords. For example, if the novel word adaptation is to examine how English $/ \mathrm{sC} /$ clusters, varying in positions, are adopted in Xitsonga, it will not always be the case that relevant loanwords will be available in order to make generalisations. This means that a loanword adaptation experiment would become necessary, as will be shown later in the article (cf. Shinohara 1997, 2015).

\footnotetext{
${ }^{2}$ We thank a reviewer who pointed out this reference to us.

${ }^{3}$ In all the examples, high $(\mathrm{H})$ tones are marked with an acute accent, and toneless syllables are unmarked.

${ }^{4}$ Gouskova (2001) provides a detailed analysis of behaviours of such epenthetic vowels across languages.
} 
However, limiting the consideration to these types of words in loanword phonology studies would only give us a partial picture of nativisation processes. We assume that speakers actively use their own grammar during the nativisation process, either through production or through perception. Therefore, this study adopts a broader definition of loanwords by including any non-native words regardless of their status in the Xitsonga lexicon. While an inclusion of such words may create a bias toward access to the donor language grammar, the same nativisation process should emerge when patterns of novel adaptations are compared with existing loans.

Theories of loanword phonology generally work under the assumption that the sound adaptation process in a recipient language is global rather than local (Silverman 1992; Peperkamp, Vendelin, and Nakamura 2008; Paradis and LaCharité 2009). These theories on segmental adaptation in loanwords provide explanations for sound changes that occur when the recipient language (e.g. Korean) nativises words from the donor language (e.g. English). For example, $/ \mathrm{s} /$ in the donor language of English is adapted as [ $\mathrm{J}]$ in the recipient language of Korean before an epenthetic vowel [i]: in the case of 'seep', /sip/ to [ $\left.\mathrm{Jip}^{\mathrm{h}} \mathbf{i}\right]$ in Korean.

None of the theories on loanword adaptation predict the variable nativisation pattern in Xitsonga because this language already has the alveolar fricative /s/in the sound inventory. A more detailed overview and further discussion of these theories on loanword adaptation can be found in Adler (2006). In the P-Map theory (see Steriade 2009, among others), the adaptation of $/ \mathrm{s} /$ to [J] is predicted because these two sounds are perceptually similar. The mapping between them is all the more similar due to the epenthetic vowel [i], which creates a phonological environment where $/ \mathrm{s} /$ is palatalised to [J] across languages. Even so, the theory cannot address why the adaptation to the palatal [S] occurs when Xitsonga speakers can utilise /s/ in their inventory. The Perceptual Assimilation Model (Best 1995) explains that the recipient language would adopt $/ \mathrm{s} / \mathrm{as}[J]$ because /s/ is assimilated to [J] (in the environment before [i]) in the perception by speakers of the recipient language, though this perceptual assimilation is unexpected since Xitsonga does not need to perceptually assimilate /s/. In the "Theory of Constraints and Repair Strategies" (TCRS; Paradis 1988; Paradis and LaCharite 1997, 2009), the adaptation of /s/ to [J] is based on the Preservation Principle in which speakers of the recipient language preserve core features of the sound $(/ \mathrm{s} /)$ in the donor language when $/ \mathrm{s} /$ is not available to them. Xitsonga has $/ \mathrm{s} /$, meaning that the TCRS does not explain the pattern in Xitsonga either.

While all three of these theories could explain the adaptation of English /s/ to Xitsonga [J], as in 'skate' as [Siketi] in (1a), none can adequately explain why this adaptation process is not applied in (1b) when 'scat' is adapted as [siketi]. There are two reasons for this. First, Xitsonga has both $/ \mathrm{s} /$ and $/ \mathrm{J} /$ in the surface phonology. The presence of $[\mathrm{s}]$ in Xitsonga suggests that the adaptation to [S] is not due to a lack of a corresponding sound in Xitsonga. Thus, "nativizationthrough-production" (Calabrese and Wetzels 2009) would not be the reason for this observed adaptation pattern. Under previous theories, we predict that $/ \mathrm{s} /$ of a donor language should uniformly be adapted as [s] in Xitsonga.

Second, Calabrese and Wetzels' (2009) "nativization-through-perception" does not satisfactorily explain the pattern either. Xitsonga does not have a phonological rule in which an underlying /s/ becomes palatalised to [S] before [i]. Such a rule would have predicted a nativisation pattern where $/ \mathrm{s} /$ is adapted as [J], as in (1a), without providing much explanation for the example in (1b). It is also the case that the variation is not sensitive to epenthetic vowels versus underlying vowels since both [i] vowels after the initial fricatives are epenthetic. 
The variation in the initial position presented in (1) contrasts with the examples in (2), where /s/ is uniformly adapted as [s] in non-initial positions. This means that Xitsonga speakers do not use the adaptation-to-[J] strategy in these positions. This asymmetric pattern of adaptation is puzzling when considered in terms of perception-based theories because the position of $/ \mathrm{s} /$ in the donor language affects the adaptation pattern (cf. "unnecessary adaptation", Peperkamp 2005). ${ }^{5}$
a. [desíkítopo]
b. [desíka]
'desktop'
'des

non-initial position

non-initial position

In sum, the adaptation pattern in Xitsonga is interesting because the one source segment, /s/ in English, is adapted in two different ways in the same word-initial position. Moreover, the Xitsonga examples are interesting because nativisation of loanwords is sensitive to positions where $/ \mathrm{s} /$ in non-initial positions never undergoes palatalisation.

After running a loanword adaptation experiment and reporting the patterns of the adaptation of the $/ \mathrm{sC} /$ clusters in these various positions, we argue here that the variations found in (1) are due to the morphological pressures in the grammar; adapting /s/ to [J] creates a sequence that is equivalent to the Xitsonga class 7 prefix [ $[\mathrm{i}-]$. By proposing a loanword adaptation case that shows the effect of morphology in phonological loanword adaptations, we add a subtype to Calabrese and Wetzels' (2009) "nativization-through-production", though this pattern is underreported in the literature.

The rest of the article is organised as follows: first, a brief introduction of Xitsonga phonology and its loan phonology is presented in section 2. Then, in section 3, a loanword experiment on Xitsonga grammar and its results will show that there is indeed a positionally-sensitive variation in Xitsonga loan adaptation. Finally, section 4 discusses various issues related to morphological reanalysis shown in Xitsonga nativisation process.

\section{Xitsonga: Native phonology and loanword phonology}

Xitsonga (S53, Guthrie 1967-1971) is a southern Bantu language spoken in South Africa, Mozambique, and Zimbabwe. The language is spoken by around 3.3 million people, and it is one of the 11 official languages of the Republic of South Africa. Xitsonga is used in all domains of life, and it shares linguistic space with Tshivenda and Northern Sotho (Sepedi). Xitsonga is also taught in the education system, up to tertiary level at the University of Venda.

As in other Bantu languages, Xitsonga organises nouns into various classes. Noun classes are described with roman numerals, where odd numbers represent singulars and even numbers denote plurals. In Xitsonga, the prefix for noun class 1 is [mu-], and the prefix for its plural counterpart, noun class 2, is [ $\beta \mathrm{a}-]$. Representative noun class prefixes are shown in Table 1.

\footnotetext{
${ }^{5}$ A similar case can be found in the loanword adaptation of consonants in Japanese. The word 'bat' is adopted as [bat.to], with the coda consonant being realised as a geminate consonant. In contrast, the word 'butter' is adopted as [ba.taa], where the onset consonant is not realised with a geminate (cf. Kubozono et al. 2009).
} 
Table 1: Xitsonga noun class prefixes, from noun class 1 to noun class 10

\begin{tabular}{|c|c|c|c|c|c|c|c|}
\hline $\begin{array}{c}\text { Noun } \\
\text { Class }\end{array}$ & $\begin{array}{c}\text { Noun } \\
\text { Class }\end{array}$ & & $\begin{array}{c}\text { Noun } \\
\text { Class }\end{array}$ & & $\begin{array}{c}\text { Noun } \\
\text { Class }\end{array}$ & \\
\hline 1 & {$[\mathrm{mu}-]$} & 2 & {$[\beta \mathrm{a}-]$} & 7 & {$\left[\int \mathrm{i}-\right]$} & 8 & {$\left[\mathrm{si}^{6}\right]^{6}$} \\
\hline 3 & {$[\mathrm{mu}-]$} & 4 & {$[\mathrm{mi}-]$} & 9 & {$[\mathrm{ji}]$} & 10 & {$[\mathrm{ti}]$} \\
\hline 5 & {$[\mathrm{ri}-]$} & 6 & {$[\mathrm{ma}-]$} & & & & \\
\hline
\end{tabular}

In Xitsonga, as the near-minimal triples in (3) show, three voiceless sibilants - [s], [S], and [s] - are contrastive in the surface (cf. Baumbach 1987, Lee 2009, and Vratsanos and Kadenge 2017 for the full consonant chart). Moreover, Xitsonga does not have a neutralisation process that palatalises /s/ to [J] before [i], regardless of whether [i] is epenthetic or underlying.

(3) Near-minimal triplets
a. [s]
[ku-síka]
'to be starving'
b. $\left[\int\right]$
[ku-jika]
'to descend straight down'
c. [s]
[ku-síra]
'to be improper'

After an examination of a Xitsonga-English dictionary (Cuenod 1966), numerous examples of loanwords can be found that include $/ \mathrm{sC} /$ clusters in donor languages. These loanwords change $/ \mathrm{s} /$ in the donor language to [J], as shown in (4).

\begin{tabular}{|c|c|c|}
\hline [Sikólo] & 'school' & (from Afrikaans) \\
\hline [Jipaneri] & 'spanner' & (from English) \\
\hline [Sipéle] & 'textbook' & (from English 'speller') \\
\hline [Sitevele] & 'stable' & (from English) \\
\hline [ $\left.\int i t i ́ m u\right]$ & 'steam' & (from English) \\
\hline [Sitóló] & 'store' & (from English) \\
\hline [Sitófu] & 'stove' & (from English) \\
\hline
\end{tabular}

Variations in the adaptation have been observed previously during fieldwork conducted by the first author in 2010 . While /s/ is mostly adapted as [J], as in (5a), this is not always the case, as shown in (5b). The starred forms with a palatal were not observed in the dataset analysed in this study.

a. Expected patterns (with [S])

$\begin{array}{lll}/ \mathrm{sp} / & {[\text { [ipesi] }} & \text { 'space' } \\ / \mathrm{st} / & {[\text { [itolo] }} & \text { 'store' } \\ / \mathrm{sk} / & {[\text { [ikete] }} & \text { 'skirt' }\end{array}$

b. Unexpected patterns (with [s])

$\begin{array}{llll}/ \mathrm{sp} / & {[\text { sipini }]} & \text { 'to spin' } & *\left[\int \text { ipini }\right] \\ / \mathrm{st} / & {[\text { sitere }]} & \text { 'to stir' } & *[\text { Sitere }] \\ / \mathrm{sk} / & {[\text { sikoto }]} & \text { 'Scott (name) } & *[\text { Sikoto }]\end{array}$

Variation in phonology is pervasive (see Labov 1972, Coetzee 2016, among others). This adaptation of $/ \mathrm{s} / \mathrm{with}$ variation in Xitsonga is therefore expected. In the absence of a systematic

\footnotetext{
${ }^{6}$ Notation for whistled fricatives follows the proposal in Lee-Kim, Kawahara and Lee (2014).
} 
study, we decided to find out whether this variation extends to cases in which /sC/ clusters occur in non-initial positions. An answer to this inquiry required a loanword adaptation experiment by using a constructed dataset specific to the questions we plan to answer in (6). In the following section, the results of an experimental investigation show that palatalisation in adopting the $/ \mathrm{s} /$ of $/ \mathrm{sC} /$ clusters is limited to the initial position. This limited variation of $/ \mathrm{s}-/$ adaptation will be argued to be a result of a pressure in the grammar so that loanwords are compatible with the native (nominal) paradigm ${ }^{7}$. The appearance of an epenthetic vowel [i] in adapting $/ \mathrm{sC} /$ clusters is a repair strategy so that the loanwords conform to the syllable structure of Xitsonga.

\section{An experiment searching for loanword grammar in Xitsonga}

This section aims to answer the two questions stated in (6).

Research questions

a. Does the variation of $/ \mathrm{s} /$ in clusters appear in all positions? Or is it limited to the word-initial position?

b. If this variation is limited to the word-initial position, what is the motivation for producing /s/ as [S]?

Existing loanwords are not diverse enough to address these questions. To answer the two research questions posed in (6), an experimental method was devised so that the Xitsonga speaker recruited for this study was required to change English words to Xitsonga. The experiment is designed to undertake an investigation of patterns in both existing and innovative loanwords in case they behave differently. If the adaptation pattern of $/ \mathrm{s} /$ in existing loanwords is due to lexicalisation, we predict that innovative loanwords may not pattern in the same way as these lexicalised loanwords.

\subsection{Methodology}

Three types of clusters were used as targets, namely $/ \mathrm{sp} /, / \mathrm{st} /$, and $/ \mathrm{sk}^{8} /$. English words containing these three clusters were collected, and the positions of these clusters varied within each word: initial, middle, and final. Clusters in the initial position were further divided into two groups depending on the presence of a liquid following / $\mathrm{sC} /$ clusters. A total of 109 target words were used as stimuli (see section 3.2 for the stimuli). The vowel following $/ \mathrm{sC} /$ clusters was not controlled. The number of words in each category appears in Table 2.

Table 2: Number of stimuli in the current study

\begin{tabular}{lcccc|c}
\hline & $\begin{array}{c}\text { Initial } \\
\text { /sC-/ }\end{array}$ & $\begin{array}{c}\text { Initial } \\
\text { /sCL-/ }\end{array}$ & $\begin{array}{c}\text { Middle } \\
\text { /-sC-/ }\end{array}$ & $\begin{array}{c}\text { Final } \\
\text { /-sC/ }\end{array}$ & $N$ \\
\hline$/ \mathrm{sp} /$ & 13 & 9 & 7 & 6 & 35 \\
$/ \mathrm{st} /$ & 14 & 11 & 6 & 8 & 39 \\
$/ \mathrm{sk} /$ & 12 & 8 & 7 & 8 & 35 \\
\hline$N$ & 39 & 28 & 20 & 22 & $\mathbf{1 0 9}$ \\
\hline
\end{tabular}

\footnotetext{
${ }^{7}$ Roots of Xitsonga nouns are predominantly monosyllabic or disyllabic, but longer loanwords from a donor language still pattern in the way reported in this article.

${ }^{8}$ The spelling variants 'sc-' and 'sk-' of /sk/ were not controlled in this experiment.
} 
The stimuli were recorded by one female native speaker of Xitsonga who was visiting the United States for a month as a visiting scholar. The speaker lives in Mhinga, Limpopo, and uses Xitsonga in all domains of her life. She has been educated up to tertiary level in Xitsonga, and recently became a Xitsonga teacher at a local primary school. The speaker is also proficient in English but not in any other official South African languages. English was the medium of instruction for most of her school subjects only after the fourth grade of her education.

The speaker was instructed to read aloud the stimuli, written English words, as if they were spoken by a Xitsonga speaker who has had little exposure to English. The speaker reported that she imagined her mother or grandmother's speech of English, both of whom have limited knowledge of English and only speak Xitsonga. The stimuli were visually presented in a randomised manner using alphabetic characters to be read twice in a carrier sentence. The carrier sentence was constructed in a toneless context to avoid any effects of high tone spreading reported in Xitsonga (cf. Kisseberth 1994, Lee 2014, among others).

$$
\begin{array}{lll}
\text { ni tịisa } X \text { laha } & \text { Toneless context } \\
\text { 'I use X here' } & (\mathrm{X}=\text { target })
\end{array}
$$

At the end of the recording session, 218 tokens $(\mathrm{N}=218,109 \times 2)$ were generated as a single WAV file. These tokens were then processed using three different Praat (Boersma 2001) scripts that were freely available online. The first script marked margins on an automatically created text tier. These margins were marked based on pauses in the single long sound file generated by the recording session. The intervals between pauses contain sound portions which were then annotated by hand. The second script cut this annotated textgrid into individual textgrid files, along with corresponding sound files, in a designated folder. At the end of this procedure, $218 \mathrm{WAV}$ files and 218 corresponding textgrid files, named after the annotation, were created. The identification process of fricatives proceeded with the third script that automatically opened each individual WAV file in succession. Any change that was made during the audio-visual examination of the fricative was automatically saved to the textgrid file before advancing to the next sound file.

Measurements of Centre of Gravity (COG) were extracted using Praat's "spectral moments of fricative spectra script" (DiCanio 2013). This script generates four spectral moments from fricative spectra by averaging discrete fourier transform (DFT) at $15 \mathrm{~ms}$ intervals with a 300 $\mathrm{Hz}$ low pass cut off. Formant values of vowels following a fricative were obtained using a script (Lennes and McCloy 2003) which extracts duration as well as the midpoint of F0, F1, and F2 from a labelled interval.

The spectrograms in Figure 1 show that both $[\delta]$ and $[\mathrm{s}]$ are produced by the speaker. The vertical axis in the spectrograms is in the scale of $10 \mathrm{KHz}$. Measurements of COG of the two fricatives are used to confirm the different place of articulation, in which [J] in Figure 1a has a lower COG value than [s] in Figure $1 \mathrm{~b}$ (cf. Lee-Kim et al. 2014). The difference in COG values (marked by curly brackets in Figure 1) is also visible on the spectrograms. 


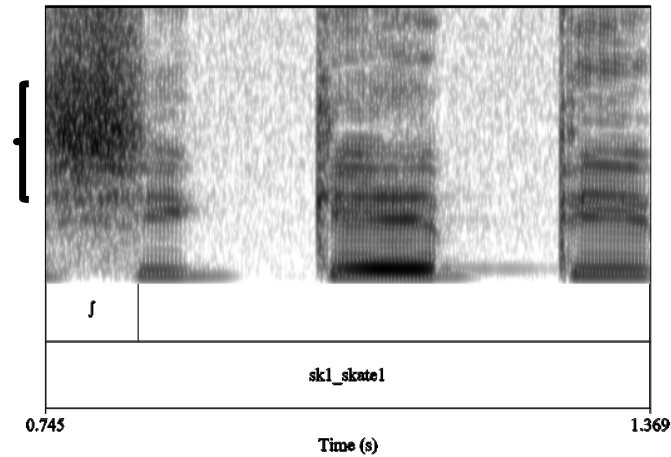

Figure 1a. Spectrogram of 'skate' produced in nativised Xitsonga.

[Sikéti] 'skate' (COG of [J] $=5348.63 \mathrm{~Hz})^{9}$

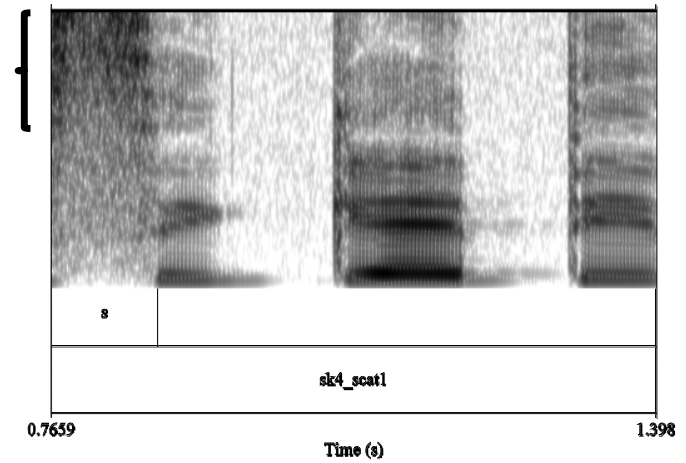

Figure 1b. Spectrogram of 'scat' produced in nativised Xitsonga. [sikéti] 'scat' (COG of [s] $=9754.82 \mathrm{~Hz})$

\subsection{Results}

\subsubsection{Descriptive results}

A positional asymmetry is found in the adaptation of /s/. In non-initial positions (middle and final in the original English words), the $/ \mathrm{s} / \mathrm{in} / \mathrm{sC} /$ clusters is consistently adapted as [s]. Realisations of $/ \mathrm{sC} /$ clusters in word-medial position are shown in (8). Regardless of the place of articulation of the stop that follows $/ \mathrm{s} /$, it is adapted as [s]. Note that an epenthetic vowel that breaks $/ \mathrm{sC} /$ clusters varies between [i] and [i] after [s], with no immediately observable pattern ${ }^{10}$.

$/ \mathrm{sC} /$ clusters in medial position

\begin{tabular}{l|l|l|l|l|l} 
a. [-sp-] & \multicolumn{5}{|c}{ b. [-st-] } \\
girasípíni & 'grasping' & akasítámu & 'accustom' & maskáráta & 'muskrat' \\
kirisípí & 'crispy' & isitéréne & 'eastern' & filásíki & 'flasks' \\
kilasípídi & 'clasped' & hosítédzi & 'hostage' & desíkítopo & 'desktop' \\
hosípítali11 & 'hospital' & konisítíreti & 'constraint' & masíkíni & 'masking' \\
koresípóndete & 'correspondent' & sesítére & 'sister' & tasíkídi & 'tasked' \\
sasipékíta & 'suspect' & zesíti & 'zesty' & askíni & 'asking' \\
selisípípulu & 'salespeople' & & & saítósíkeletoni & 'cytoskeleton'
\end{tabular}

Clusters in the final position of the donor language of English are shown in (9). As in (8), /s/ from English is uniformly adapted as [s]. Unlike the examples in (8), there is no variation between [i] and [i] in (9). Note that a vowel inserted after the final stop shows variation between [i] and [a]. This variation will not be discussed further as it is beyond the scope of this article.

\footnotetext{
9 The y-axis in both figures is from 0 to $10000 \mathrm{~Hz}$.

${ }^{10}$ A reviewer asked whether the high central vowel [i] mainly occurs before an [e] vowel. Examples in (12) and (13) show that this is not the case.

${ }^{11}$ A reviewer observed that multiple forms in the dataset violate the *LI constraint (Bennett and Lee 2015). This exception is observed probably because loanwords belong to a different lexical stratum than native words (Itô and Mester 2009). Even in Bennett and Lee (2015), the * LI constraint is violated when a verbal root is followed by a negative suffix /-i/: [ $\mathrm{a} a \beta e l a]$ 'to buy for' and [ $\mathrm{a} \beta \mathrm{\beta el}-\mathrm{i}]$ 'to buy for - NEG'.
} 
(9)

\begin{tabular}{|c|c|c|c|c|c|}
\hline \multicolumn{2}{|l|}{ a. $[-\mathrm{sp} \#]$} & \multicolumn{2}{|l|}{ b. $[-s t \#]$} & \multicolumn{2}{|l|}{ c. $[-\mathrm{sk} \#]$} \\
\hline wasípá & 'wasp' & tirasita & 'trust' & desíka & 'desk' \\
\hline girasípá & 'grasp' & biresítí & 'breast' & asíka & 'ask' \\
\hline kirisípí & 'crisp' & wesítá & 'waste' & masíkí & 'mask' \\
\hline kasípí & ‘cusp’ & akosítí & 'accost' & birisíkí & ‘brisk’ \\
\hline lisípí & 'lisp' & olímósiti & 'almost' & hasíkí & 'husk' \\
\hline wisípí & ‘wisp' & hepíésiti & 'happiest' & asítérisíkí & 'asterisk' \\
\hline & & bosítá & 'boast' & molasíkí & 'mollusc' \\
\hline & & kasítí & 'cast' & kiosíkí & 'kiosk' \\
\hline
\end{tabular}

In the initial position, /s/ is adapted with variations, as [S] or [s]. The lists in (10) and (11) show $/ \mathrm{sC} /$ adaptation in the initial position without and with a liquid sound in the onset. The data that are enclosed in a box are examples that adapt /s/ to [s] instead of [J]. While the quality of an epenthetic vowel varies between [i] and [i] after [s], there is no such variation after [S]: an epenthetic vowel is always [i]. No palatalisation is observed before the central high [i] vowel.

\begin{tabular}{|c|c|c|c|c|c|}
\hline a. [\#sp-] & & b. [\#st-] & & c. $[\#$ sk- $]$ & \\
\hline $\begin{array}{l}\text { Jipúnú } \\
\text { Jipóto } \\
\text { Jipúwu } \\
\text { Jipáka } \\
\text { Jipédi } \\
\text { Jipédi } \\
\text { Jipídi } \\
\text { Jipainali } \\
\text { Jipóto } \\
\text { sipíni } \\
\text { sipána } \\
\text { sipáno }\end{array}$ & $\begin{array}{l}\text { 'spoon' } \\
\text { 'sport' } \\
\text { 'spew' } \\
\text { 'spark' } \\
\text { 'spade' } \\
\text { 'sped' } \\
\text { 'speed' } \\
\text { 'spinal' } \\
\text { 'spot' } \\
\text { 'spin' } \\
\text { 'span' } \\
\text { 'spun' }\end{array}$ & $\begin{array}{l}\text { Jitere } \\
\text { Jitíki } \\
\text { Jitóko } \\
\text { Jitámáka } \\
\text { Jitúlú } \\
\text { Jitíwu } \\
\text { Jitéji } \\
\text { Jitídi } \\
\text { Jitídi } \\
\text { Jitafu } \\
\text { Jitédzi } \\
\text { Jitét }{ }^{h} i \\
\text { sitére } \\
\text { sitanítgi }\end{array}$ & $\begin{array}{l}\text { 'stare' } \\
\text { 'stink' } \\
\text { 'stock' } \\
\text { 'stomach' } \\
\text { 'stool' } \\
\text { 'stew' } \\
\text { 'stay' } \\
\text { 'stead' } \\
\text { 'steed' } \\
\text { 'stuff' } \\
\text { 'stage' } \\
\text { 'stitch' } \\
\text { 'stir' } \\
\text { 'staunch' }\end{array}$ & $\begin{array}{l}\text { Jikéti } \\
\text { Jikóni } \\
\text { Jikáji } \\
\text { Jikanka } \\
\text { Jikéme } \\
\text { Jikárá } \\
\text { Jikími } \\
\text { Jikeletoni } \\
\text { Jikími } \\
\text { Jikóró } \\
\text { sikéti } \\
\text { sikirímífi }\end{array}$ & $\begin{array}{l}\text { 'skate' } \\
\text { 'scone' } \\
\text { 'sky' } \\
\text { 'skunk' } \\
\text { 'scam' } \\
\text { 'scar' } \\
\text { 'scheme' } \\
\text { 'skeleton' } \\
\text { 'skim' } \\
\text { 'score' } \\
\text { 'scat' } \\
\text { 'skirmish' }\end{array}$ \\
\hline
\end{tabular}

(11) $/ \mathrm{sC} /$ followed by a liquid in initial position

\begin{tabular}{|c|c|c|c|c|c|}
\hline a. [\#spL-] & & b. [\#stL-] & & c. [\#skL-] & \\
\hline Sipiréi & 'spray' & Sitérádili & 'straddle' & Jikeréthe & 'scratch' \\
\hline Jipíri & 'spree' & fitirípi & 'strip' & jikwája & 'squire' \\
\hline Sipiráwúti & 'sprout' & jiterápu & 'stripe' & fikirapúlási & 'scrupulous' \\
\hline sipírángi & 'sprung' & Jitiródu & 'strode' & fikirímédzi & 'scrimmag \\
\hline sipúládzi & 'splurge' & Jitirówu & 'straw' & fikírólo & 'scroll' \\
\hline sipílíni & 'spleen' & siteráífa & 'strife' & Jikeríni & 'screen' \\
\hline sipílíta & 'split' & sitiréti & 'straight' & Jikwére & 'square' \\
\hline sipiláísi & 'splice' & sitiróla & 'stroll' & sikúru & 'screw' \\
\hline sipúláti & 'splat' & sitiríki & 'streak' & sikirími & 'scream' \\
\hline & & $\begin{array}{l}\text { sitiréngi } \\
\text { sitiróno }\end{array}$ & $\begin{array}{l}\text { 'strength' } \\
\text { 'strewn' }\end{array}$ & & \\
\hline
\end{tabular}

An overall result is shown in Table 3 . In general, $/ \mathrm{s} /$ is adapted to [ $\left.\int\right]$ four times as much as it is adapted to [s] (32 times vs. 7 times) when there are no liquids following it. If a liquid follows a $/ \mathrm{sC} /$ cluster, then there is an equal chance of $/ \mathrm{s} /$ being adapted as $[S]$ or [s] (14 times each). A /spl/ cluster in the initial position would always adapt to [s] - a pattern that is not observed in any other clusters. The behaviour of the /spl/ cluster adds another piece of evidence as to why phonology alone cannot explain the variation found in the Xitsonga data. 
Table 3: Adaptation of English /s/ in initial positions

\begin{tabular}{|c|c|c|c|}
\hline Initial position & [J] & [s] & \\
\hline a. /sp-/ & 10 & 3 & 13 \\
\hline /st-/ & 12 & 2 & 14 \\
\hline /sk-/ & 10 & 2 & 12 \\
\hline sum & 32 & 7 & \\
\hline b. $/$ spr-/ & 3 & 1 & 4 \\
\hline /spl-/ & 0 & 5 & 5 \\
\hline /str-/ & 5 & 6 & 11 \\
\hline /skr-/ & 6 & 2 & 8 \\
\hline sum & 14 & 14 & \\
\hline $\mathrm{N}=$ & 46 & 21 & $\mathrm{~N}=67$ \\
\hline
\end{tabular}

\subsubsection{Statistical results}

Statistical analyses using R (R Core Team 2018) were performed in order to examine the patterns of fricatives in Xitsonga loanwords. From the four spectral moments obtained (DiCanio 2013), we focus on the COG, a measure that shows the differences between places of articulation in fricatives: the alveolar fricative $[\mathrm{s}](\mathrm{n}$ of DFTs $=132$, mean $=10199 \mathrm{~Hz})$ has a higher COG than the palatal fricative $\left[\int\right]$ ( $\mathrm{n}$ of DFTs $=96$, mean $=5576 \mathrm{~Hz}$ ). The Shapiro-Wilk normality test shows that both COG values of $[\mathrm{s}](\mathrm{W}=0.96, \mathrm{p}<0.01)$ and that of $\left[\int\right](\mathrm{W}=0.92$, $\mathrm{p}<0.01)$ approach normal distribution. A two-tailed t-test shows that the difference in COG between [s] and [J] is significant: $\mathrm{t}(221.19)=93.61, \mathrm{p}<0.01$.

The vowel following a fricative is usually [i], but it is realised with a central high vowel [i] after the alveolar fricative [s]. We tested this vowel difference by testing the midpoints of F1 and F2. Since both vowels are high vowels, we did not expect any statistical difference between [i] $(n=173)$ and [i] $(n=43)$ in terms of $F 1$, which shows an inverse relationship with the vowel height. We first ran the Shapiro-Wilk normality test to examine whether the dataset is normally distributed. In terms of F1 midpoint, both F1 measurements of [i] $(\mathrm{W}=0.97, \mathrm{p}<0.01)$ and those of [i] $(\mathrm{W}=0.89, \mathrm{p}<0.01)$ were in normal distribution. A two-tailed t-test shows that the difference in F1 midpoint values of [i] and [i] is statistically insignificant $(\mathrm{t}(56.28)=-1.3045$, $p=0.1974)$, indicating that both vowels can be said to be in the same height.

The next step of the statistical test was to examine the distribution of the F2 midpoint using the Shapiro-Wilk normality test. The results show that the F2 measurements in both [i] (W=0.67, $\mathrm{p}<0.01)$ and $[\mathrm{i}](\mathrm{W}=0.80, \mathrm{p}<0.01)$ are normally distributed. The results of a two-tailed t-test show that the difference in the F2 midpoint values of [i] and [i] are statistically significant $(\mathrm{t}(50.608)=5.7305, \mathrm{p}<0.05)$, with the $[\mathrm{i}]$ vowels displaying lower F2 midpoint values. ${ }^{12}$

\subsection{Summary}

In Xitsonga phonotactics, the $/ \mathrm{sC} /$ consonant cluster is not allowed in a syllable, or in word-initial position, or in the non-initial position of a word. The clusters with the $/ \mathrm{sC} /$ sequence do not appear word-medially either because Xitsonga does not permit [s] codas, which would be created if a

\footnotetext{
${ }^{12}$ A reviewer questioned whether the speaker showed any durational difference between [i] and [i]. The results of a ttest show that there is no significant difference between the duration of the two vowels: $\mathrm{t}(73.41)=1.6693, \mathrm{p}=0.09$.
} 
heterosyllabic cluster (such as [...s.C...]) is assumed ${ }^{13}$. Thus, the [i] vowel is internally epenthesised to break the clusters in words that come from the donor language, English.

\section{Discussions}

\subsection{Grammatical evidence}

The variable palatalisation in Xitsonga loans only occurs in initial position. We argue that palatalisation occurs when the result of loan adaptation is analysed as the class 7 prefix form 'xi-' [ [1-] (see a similar case in Sesotho - Demuth 2000: 280). In the loanword adaptation process, speakers perceive /sC-/ initial loanwords as nouns, and they know that nouns have class prefixes. With the epenthetic vowel [i], loanwords begin with the syllable [si]. Speakers analyse the [si-] part of loanwords as [Ji-], the class 7 prefix.

Pluralisation is one of the arguments for the morphology-driven nativisation in the loanword adaptation. The speaker for this study was asked the question "If there are two (nouns), how do you say that in Xitsonga?". In plurals, the class 7 [ $\left.\mathrm{ji}^{-}\right]$prefix becomes the class 8 [si-] prefix, as in (12a). This pluralisation process was also observed in existing loanwords, in (12b), and novel loanwords produced by the speaker, as in (12c). This suggests that the Xitsonga speaker indeed treates the [ji-] initial loanwords as class 7 nouns.

a. Native words

$$
\begin{aligned}
& \text { [ } \int i-\text { hontloßila] 'a giant' } \\
& \text { [Si-loka] 'an axe' } \\
& \text { [Ji-mayga] 'a cat' }
\end{aligned}
$$

$$
\begin{aligned}
& \text { [si-fontloßila] 'giants' } \\
& \text { [si-łoka] 'axes' } \\
& \text { [si-manga] 'cats' }
\end{aligned}
$$

b. Existing loanwords

$\begin{array}{llll}{\left[\int 1-k o ́ l o\right]} & \text { 'a school' } & \text { [si-kólo] } & \text { 'schools' } \\ {\left[\int 1-p e ́ l e\right]} & \text { 'a textbook' } & \text { [si-péle] } & \text { 'textbooks' } \\ {\left[\int 1-t o ́ f u\right]} & \text { 'a stove' } & \text { [si-tófu] } & \text { 'stoves' }\end{array}$

c. Loanwords (from the stimuli)

$\begin{array}{llll}{\left[\int 1-p u n u\right]} & \text { 'a spoon' } & {[\text { si-punu }]} & \text { 'spoons' } \\ {\left[\int 1 \text {-tiripi] }\right.} & \text { 'a strip' } & {[\text { si-tiripi] }} & \text { 'strips' }\end{array}$

Xitsonga has an object clitic system that agrees with the antecedent in terms of the noun class (gender and number). The example in (13a) shows that the antecedent [ 1 i-tófü] 'CL7-stove' is referred to by the class 7 object prefix [ $\mathrm{ji}]$ in the second clause. This agreement pattern also shows that the /sC/ loanwords are adapted as a class 7 noun. The example in (13b) has the noun phrase 'two big stoves', where the modifiers of the head noun 'stoves' have the class 8 prefix to indicate agreement with the head noun [șì-tófù] 'CL8-stove'.

\footnotetext{
${ }^{13}$ Two exceptions were found in the dataset: [maskarata] 'muskrat' and [askini] 'asking'. This is possibly due to the influence of English on the consultant's speech.
} 
Agreement

a. Object-pronoun agreement

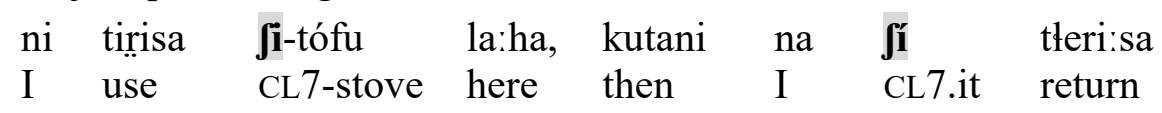

'I use a stove here, then I return it.'

b. DP-internal agreement
ni aßßile si-tófu
si -mbíri
sii-kúlú
tó:lo
I bought CL8-stove CL8-two
CL8-big
yesterday

'I bought two big stoves yesterday'

Morphological reanalysis is also supported by the literature on morphological priming. Stockall and Marantz (2006: 85) argue that "all complex words assembled by the grammar come from lexical roots and functional morphemes", even in irregular forms. This type of morphological priming would result in morphological reanalysis during the nativisation of loanwords. Thus, Xitsonga speakers morphologically reanalyse forms into lexical roots and functional morphemes - class prefixes in Xitsonga. The reanalysis is a relatively simple process that occurs by changing [s-] to [S] in the initial position.

Additionally, it is more likely that loans enter the lexicon of the recipient language as nouns irrespective of their part of speech in the donor language (cf. Morimoto 2000). For example, English words that come into Korean are commonly assigned to the part of speech of nouns. When '(to) pass' in English entered the Korean lexicon, the form needed to be augmented by the light verb suffix [-hada] - literally, 'to do' - in order to be used in a full Korean sentence. It is highly likely that Xitsonga speakers follow this pattern of morphological loan adaptation.

It is common for loanwords to be classified with the morphology of a productive class. (cf. Dressler 2003). In Xitsonga, the noun class 7 is a morphologically productive class (the same class has also been observed to be productive in Sesotho - see Demuth 2000: 278-279). In addition to denoting the semantic class of 'languages', the prefix [ $[1-]$ marks diminutive forms

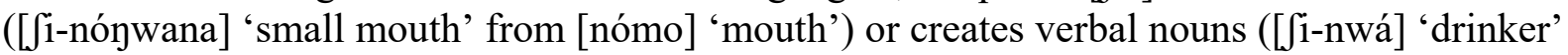
from [nwá] 'to drink'). Xitsonga words with the prefix [ $\left.\int i-\right]$ are favoured by younger speakers over other types of prefixes (cf. the noun class system in Table 1). If there are two words with a similar meaning, younger speakers prefer forms using [ji-], or they only know the forms with the prefix [ $[\mathrm{i}-]$. These factors all suggest that class 7 is the default noun class in Xitsonga.

The pressure to produce a palatalised sound may be due to the phonological shape of the morpheme $/ \mathrm{si}$-/. Xitsonga speakers may insert [i] to repair the phonotactic violation in $/ \mathrm{sC} /$ clusters, but they know that doing so will potentially create a prefix-less noun. An independent pressure to create a loanword noun in the default class may be greater and, in response, speakers produce a palatal sound.

The adaptation-to-noun strategy, however, is not without exceptions. Combined with the morphological reanalysis, it is predicted that loanwords that are not adapted as nouns may not exhibit the palatalisation process - the only way to know whether or not a given loanword is reanalysed as a class 7 noun. A list of loanwords that do not undergo palatalisation in the initial position is shown in (14). The words in (14) are the experimental items that were used to test this prediction. 
The results show that the Xitsonga speaker could have accessed her knowledge of grammatical categories in English when she provided information about the loanword grammar. Alternatively, the speaker could have defaulted to [s] when she was not sure about the category of a word in English. The words in (14a), such as '(to) span', 'to stir' etc., are not necessarily nouns, and yet the speaker opted for the [s] realisation. The words in (14b) are mostly verbs or onomatopoeia (exceptions being 'spleen', 'straight', 'strength', and 'strewn') with no palatalisation; if these words were treated as nouns, the speaker would have reanalysed them each into a noun.

a. $/ \mathrm{sC} /$ in initial position with $[\mathrm{s}]$ realisation

\begin{tabular}{l|l|l|l|l|l} 
[\#sp] & [\#st] & \multicolumn{3}{c}{ [\#sk] } \\
sipíni & '(to) spin' (V, N) & sitére & 'to stir’ & sikéti & 'scat' (N, V) \\
sipána & '(to) span’ (V, N) & sitanít'ti & 'staunch' (A) & sikirímífi & '(to) skirmish' (A, N, V) \\
sipáno & 'spun' & &
\end{tabular}

b. $/ \mathrm{sCL} /$ in initial position with $[\mathrm{s}]$ realisation

\begin{tabular}{|c|c|c|c|c|c|}
\hline [\#spr/spl] & & [\#str] & & [\#skr] & \\
\hline $\begin{array}{l}\text { sipírángi } \\
\text { sipúládji } \\
\text { sipílíni } \\
\text { sipílíta } \\
\text { sipiláísi } \\
\text { sipúláti }\end{array}$ & $\begin{array}{l}\text { 'sprung' } \\
\text { 'splurge' } \\
\text { 'spleen' (N) } \\
\text { 'split' } \\
\text { 'splice' } \\
\text { 'splat' }\end{array}$ & $\begin{array}{l}\text { siteráífa } \\
\text { sitiréti } \\
\text { sitiróla } \\
\text { sitiríki } \\
\text { sitiréngi } \\
\text { sitiróno }\end{array}$ & $\begin{array}{l}\text { 'to strive' } \\
\text { 'straight' (A, N) } \\
\text { 'stroll' } \\
\text { 'streak' } \\
\text { 'strength' (N) } \\
\text { 'strewn' (A) }\end{array}$ & $\begin{array}{l}\text { sikúru } \\
\text { sikirími }\end{array}$ & $\begin{array}{l}\text { '(to) screw' }(\mathrm{N}, \mathrm{V}) \\
\text { '(to) scream' }(\mathrm{V}, \mathrm{N})\end{array}$ \\
\hline
\end{tabular}

Words that have the /spl/ initial cluster, such as 'splat', 'splurge' etc., are onomatopoeic. Invariably, these onomatopoeic words do not undergo palatalisation. Onomatopoeic words are not nouns, so speakers of Xitsonga have no reason to reanalyse them as a prefix plus a root. Hence, there is no reason for palatalisation. Faithful realisations of [s] in these words are an effective way of avoiding palatalisation, which would have resulted in morphological reanalysis.

A gap in the data is how Xitsonga speakers pluralise loanwords that are adapted with [si-]. The plural prefix of these words, if they can become plural, would be class 6 [ma-] or class 10 [ti-]. A future study of plural formation in these loanwords could test this prediction.

\subsection{Aggressive morphology}

The effect of morphology on phonological patterns has been reported elsewhere. Examining patterns of vowel raising in Tagalog reduplication, Zuraw (2002) argues that phonological patterns can occur due to morphological reason. She terms this "aggressive reduplication". This concept was inspired by Hammond (1999) who shows that suffix-less English adjectives pattern as if they are suffixed for assigning stress. Hayes and Jo (2019) argue that the pseudoreduplicated stems in Balinese allow otherwise illicit word-internal consonant sequences, suggesting that languages can parse strings into reduplicated structures even though the reduplication violates phonotactic patterns.

The pattern in Xitsonga is in line with the findings of these studies. The nativisation of the initial /s/ as a palatal in the loanword [ $\left.\int \mathrm{i}-\mathrm{kolo}\right]$ 'school' is due to morphological reasons. Moreover, Xitsonga prevents palatalisation in $/ \mathrm{sC} /$ clusters when such a boundary cannot be inserted. This pattern is interesting because loanwords do not retain morphological information 
of the donor language in the nativisation process. For example, English speakers are generally not aware of morphological boundaries such as in the Japanese loanword 'tofu', which is composed of two morphemes: [to] 'beans' and [fu] 'rotten'.

Xitsonga, however, is not alone in its insertion of a morphological boundary in $/ \mathrm{sC} /$ loanwords. In isiZulu, a morphological boundary is also inserted: 'school' is [isi-kolo], in which [isi-] is the class 7 prefix (cf. Khan 2016). In Northern Sotho, 'school' is adapted to [se-kolo], where [se-] is the class 7 prefix. For both languages, /s/ in the donor language of English does not change in either recipient language. In Shona, 'school' is realised as [ $\mathrm{g}$ i-koro]; [ $\mathrm{t}$ i- $]$ with a palatalised affricate is the class 7 prefix. If morphological reanalysis is not limited to Xitsonga, it could be that Shona also inserts a morphological boundary and changes the $/ \mathrm{s} /$ in the $/ \mathrm{sC} /$ cluster to the affricate [ $\mathfrak{g}$ ] only when the loanword is a noun. This pattern is not limited to southern Bantu languages. In Swahili, the word [ki-tabu] 'CL7-book' comes from the Arabic word [kitab] 'a book', and its plural form is [vi-tabu] 'CL8-books' ${ }^{14}$, where the root syllable /ki/ in Arabic is nativised as the class 7 prefix in Swahili. This type of nativisation is also found in a recent Swahili loanword: 'COVID-19'. The new name of the virus is translated as virusi vya korona, in which the class 8 associative marker vya shows agreement with virusi that is morphologically reanalysed as a class 8 plural noun (Covid-no-mb 2020).

\subsection{Limits of phonological explanations: Palatalisation of /s/ in Xitsonga loanwords}

As demonstrated in section 3, palatalisation in Xitsonga loanwords only occurs when /s/ appears in the word-initial position. The variation itself is not surprising because this type of variation has been reported previously in other languages. For example, in Hawaiian, which lacks coronal obstruents in the sound inventory, interdental fricatives are adapted with variation, as in (15) (Adler 2006: 1029; also see Ahn 2003 for an overview). The voiceless interdental fricative / $\theta$ / may adapt as $[\mathrm{h}]$ or $[\mathrm{k}]$, or it may result in elision.

(15) Variations in adapting interdental fricatives in Hawaiian

$$
/ \theta / \rightarrow \mathrm{h}, \mathrm{k}, \varnothing
$$

$\begin{array}{llll}\text { a. truth } & \text { kəlúhu } & {[\mathrm{h}]} & \text { word-final } \\ \text { b. telepathic } & \text { kelepáki } & {[\mathrm{k}]} & \text { word-medial } \\ \text { c. } \underline{\text { thing }} & \text { í:enə } & \emptyset & \text { word-initial }\end{array}$

Asymmetry in the phonological adaptation of /s/ has also been noted in Korean, in which a final /s/ in English is adapted as a tense [s'], while a non-final /s/ is adapted as [s]. Thus, the English word 'bus' is realised as [brs' $\mathrm{i}]$ with a tense [s'], but 'test' is realised as [ $\mathrm{t}^{\mathrm{h}} \mathrm{esit}^{\mathrm{h}}{ }_{\mathrm{i}}$ ] , with a lax [s] (see Davis and Cho 2006 for more discussions).

The results in section 3 are unique because Xitsonga has the $[\mathrm{s}] \sim\left[\int\right]$ variation only in the wordinitial position. A possible explanation is that this variation of [s] and [ $\left.\int\right]$ is due to the epenthetic vowel, [i] - a common environment for palatalisation. Previous theories on segmental loan adaptations (P-Map, the Perceptual Assimilation Model, and TCRS), however, do not predict a borrowing with [S] because of the presence of /s/ in Xitsonga. Moreover, an analysis in which a palatalisation process is triggered by an epenthetic [i] has its shortfalls. In non-initial positions, an epenthetic [i] does not trigger such palatalisation, as in [desika] 'desk'.

\footnotetext{
${ }^{14} \mathrm{We}$ thank an anonymous reviewer for drawing our attention to this example.
} 
An alternative phonological explanation is that the palatalisation in the initial position is an instance of "the emergence of the unmarked" (TETU). Recent studies on Japanese loanword adaptation report that some phonetically natural processes emerge during the nativisation process (cf. Kawahara 2008). Japanese allows geminate /ss/, but in loanword adaptation, the /ss/ geminate is avoided, compared to the /tt/ geminate (Katayama 1998, Shirai 1999). However, TETU theory cannot account for examples of the adaptation of $/ \mathrm{sC} /$ clusters in Xitsonga, nor can this theory explain why the palatalisation is limited to the word-initial position.

In sum, the observed positionally sensitive palatalisation can partially be accounted for by the perception-based theories or by TETU theory. However, the phonological explanation is not satisfactory because it fails to account fully for the non-palatalisation of $/ \mathrm{s} /$ in the non-initial position.

\subsection{Extraneous variables}

Investigating a phonological grammar with experimental methods and the interpretation of the results can always be influenced by extraneous variables that can enter at any point during the course of the study. In particular, the possibility of such influences is high in loanword studies like the one presented in this article because loanwords are defined in a broader sense, including words that have not yet entered the lexicon of Xitsonga.

The task itself can create misleading information in data collection. First, reading from English spelling could have resulted in the variation of /s/ in initial position (the "orthography effect"; see Vendelin and Peperkamp 2006). If reading the orthography were a true effect on the variations in the realisations of $/ \mathrm{s} /$ in initial positions, we would expect such variations in other positions as well. Second, asking the Xitsonga speaker to produce speech patterns as if she were a speaker with no or less knowledge of English may not correctly reflect the nature of loanword grammar in Xitsonga. We assume that the orthography effect is not great because otherwise we would have expected a more uniformed behaviour in the loanword adaptation experiment (cf. Schwade 2012).

Words that the Xitsonga speaker did not know could have had an effect on the production of /s/ (the "nonce word effect"). Even so, the speaker did not show any variations in the adaptation of $/ \mathrm{s} /$ in non-initial positions. If there were truly a nonce word effect in the production of the variations in the /s/ adaptation, we would have observed such examples in the adaptation of $/ \mathrm{s} /$ in non-initial position as well, which was not the case.

It is also possible to consider the influence of Afrikaans and English pronunciations in this initial-position-only variation. The influence of these two languages on palatalisation is very unlikely because none of these languages pronounce $/ \mathrm{s} / \mathrm{in} / \mathrm{sC} /$ clusters as the palatal [J]: in Afrikaans, the cluster is pronounced as [st-], as in the example Sterkte! 'good luck', a phrase not used by Xitsonga speakers. A less likely alternative explanation is also conceivable. Xitsonga communities in South Africa have had long contact with missionaries from Switzerland, which could be used as identifying German as a potential, but very unlikely, source for $/ \mathrm{s} /$ being realised as $[S]$ in initial $/ \mathrm{sC} /$ clusters. Attributing the adaptation to $[\delta]$ in the initial position to the influence of German would be a stretch, however, because modern Xitsonga speakers have little to no access to German, nor do most have proficiency in German. 


\section{Conclusion}

Loanword adaptation in Xitsonga shows a unique phenomenon where $/ \mathrm{s} / \mathrm{in} / \mathrm{sC} /$ clusters are variably adapted as [s] or [S], depending on their position in the word. This process, however, does not occur in non-initial positions where /s/ is uniformly adapted as [s]. This position-specific loan adaptation in Xitsonga is argued to occur when the result of variation (i.e. adaptation to [S]) can be interpreted as a class 7 noun prefix, reflecting pressure from morphology. This adaptation to $[S]$ is supported by plural formation and other morphological motivation.

\section{Acknowledgements}

We would like to thank our Xitsonga consultants, specifically Clementinah Burheni, among others. We also received valuable assistance from Prof. Mokgale Makgopa and Dr Morris Babane of the University of Venda in South Africa. We also thank Siobhan Barton who assisted with constructing the dataset. Helpful comments on an earlier version of this study came from William Bennett, Vincent Chanethom, Brian D. McHugh, Shigeto Kawahara, Jeremy Perkins, and Sharon Rose. Comments from the audiences of WOCAL 7, as well as the colloquium audiences of Gothenburg University and University of Hong Kong, were also beneficial. Various stages of this research were supported by four internal grants from Central Connecticut State University to the first author. This project has also been partially supported by two JSPS Kakenhi grants 16K02641, 20K00578, JSPS's Core-to-Core Program: B. Asia-Africa Science Platforms (2018-2020) "Establishment of a Research Network for Exploring the Linguistic Diversity and Linguistic Dynamism in Africa", and the ILCAA joint research project "Typological Study of Microvariation in Bantu (2)".

\section{References}

Adler, A.N. 2006. Faithfulness and perception in loanword adaptation: A case study from Hawaiian. Lingua 116(7): 1024-1045. https://doi.org/10.1016/j.lingua.2005.06.007

Ahn, S.C. 2003. English interdental substitution. English and Language Literature 49(5): 981-1004.

Baumbach, E.J.M. 1987. Analytical Tsonga grammar. Pretoria: University of South Africa.

Bennett, W.G. and S.J. Lee. 2015. A surface constraint in Xitsonga: *LI. Africana Linguistica 21: 3-27.

Best, C.T. 1995. A direct realist view of cross-language speech perception. In W. Strange (Ed.) Speech perception and linguistic experience: Issues in cross-language research. Timonium, MD: York Press. pp. 171-204.

Boersma, P. 2001. Praat, a system for doing phonetics by computer. Glot International 5(9/10): 341-345.

Calabrese, A. and W.L. Wetzels. (Eds.) 2009. Loan phonology. Philadelphia, PA: John Benjamins Publishing Company. https://doi.org/10.1017/s0952675711000091 
Coetzee, A. 2016. A comprehensive model of phonological variation: Grammatical and nongrammatical factors in variable nasal place assimilation. Phonology 33(2): 211-246. https://doi.org/10.1017/s0952675716000117

Covid-no-mb. 2020. COVID-19 Myth busters in world languages: Swahili. Available online: https://covid-no-mb.org (Accessed 26 April 2020).

Cuenod, R. 1966. Tsonga-English dictionary. Johannesburg: Sasavona.

Davis, S. and M.-H. Cho. 2006. Phonetics versus phonology: English word final /s/ in Korean loanword phonology. Lingua 116(7): 1008-1023. https://doi.org/10.1016/j.lingua.2005.06.006

Demuth, K. 2000. Bantu noun class systems: Loan word and acquisition evidence of semantic productivity. In G. Senft (Ed.) Classification systems. Cambridge: Cambridge University Press. pp. 270-292.

DiCanio, C. 2013. Praat Script: Time averaging for fricatives 2.0. Haskins Laboratories and SUNY Buffalo. Available online: https://www.acsu.buffalo.edu/ cdicanio/scripts.html (Accessed 25 April 2020).

Dressler, W.G. 2003. Degrees of grammatical productivity in inflectional morphology. Rivista di Linguistica 15(1): 31-62.

Gouskova, M. 2001. Falling sonority onsets, loanwords, and Syllable Contact. In M. Andronis, E. Debenport, C. Ball, H. Elston, and S Neuvel (Eds.) Proceedings of the Chicago Linguistics Society 37. Chicago: Chicago Linguistics Society. pp. 176-186.

Guthrie, M. 1967-1971. Comparative Bantu: An introduction to the comparative linguistics and prehistory of the Bantu languages. Farnborough: Gregg Press.

Hammond, M. 1999. English Stress and Cranberry Morphs. Paper presented at the Linguistics Society of America, Los Angeles.

Hayes, B. and J. Jo. 2019. Balinese Stem Phonotactics and the Subregularity Hypothesis. Unpublished manuscript. UCLA, Los Angeles.

Itô, J. and A. Mester. 2009. Lexical classes in phonology. In S. Miyagawa and M. Saito (Eds.) Handbook of Japanese linguistics. Oxford: Oxford University Press. pp. 84-106. https://doi.org/10.1017/s0952675713000079

Kang, Y. 2011. Loanword phonology. In M. van Oostendorp, C. Ewen, E. Hume, and K. Rice (Eds.) Companion to phonology. Malden, MA: Wiley Blackwell. pp. 2258-2282.

Kang, Y. 2013. Loanwords. Available online: https://doi.org/10.1093/OBO/9780199772810$\underline{0027}$ (Accessed 2 June 2020).

Karim, K. 2010. Vowel epenthesis in Bengali: An Optimality Theory analysis. Working Papers of the Linguistics Circle of the University of Victoria 20: 26-36. 
Katayama, M. 1998. Optimality Theory and Japanese loanword phonology. Unpublished $\mathrm{PhD}$ dissertation, UCSC.

Kawahara, S. 2008. Phonetic naturalness and unnaturalness in Japanese loanword phonology. Journal of East Asian Linguistics 17: 317-330. https://doi.org/10.1007/s10831-008-9030-z

Khan, T. 2016. IsiZulu Adoptives from English and Afrikaans: An Optimality Theory Analysis. Unpublished MA Thesis, University of the Witwatersrand.

Kisseberth, C.W. 1994. On domains. In J. Cole and C. Kisseberth (Eds.) Perspectives in Phonology. Stanford: Center for the Study of Language and Information. pp. 133-166.

Kubozono, H., J. Itô, and A. Mester 2009. Consonant gemination in Japanese loanword phonology. In M. Pak. (Ed.) Current issues in unity and diversity of languages: Collection of papers selected from the 18th International Congress of Linguists. Republic of Korea: Dongam Publishing Co. pp. 953-973.

Labov, W. 1972. Sociolinguistic patterns. Philadelphia, PA: University of Pennsylvania Press.

Lee, S.J. 2009. H Tone, depressors and downstep in Tsonga. In M. Matondo, F. Mc Laughlin, and E. Potsdam (Eds.) Selected proceedings of the 38th Annual Conference on African Linguistics. Somerville, MA: Cascadilla Proceedings Project. pp. 26-37.

Lee, S.J. 2014. Domains of H tone spreading and the noun class prefix in Xitsonga. Southern African Linguistics and Applied Language Studies 32(1): 21-34. https://doi.org/10.2989/ $\underline{16073614.2014 .925215}$

Lee-Kim, S., S. Kawahara, and S.J. Lee. 2014. The "whistled" fricative in Xitsonga: Its articulation and acoustics. Phonetica 71(1): 50-81. https://doi.org/10.1159/000362672

Lennes, M. and D. McCloy 2003. Collect_formant_data_from_files.praat. Available online: http://www.helsinki.fi/ lennes /praat-scripts/ (Accessed 21 August 2019).

Lombardi, L. 2003. Second language data and constraints on manner: Explaining substitutions for the English interdentals. Second Language Research 19(3): 225-250. https://doi.org/ $\underline{10.1177 / 026765830301900304}$

Morimoto, Y. 2000. Loan words and their implications for the categorial status of verbal nouns. In S.S. Chang, L. Liaw, and J. Ruppenhofer (Eds.) Proceedings of the twenty-fifth annual meeting of the Berkeley Linguistics Society. General Session and Parasession on Loan Word Phenomena. Berkeley, CA: Berkeley Linguistics Society. pp. 371-382. https://doi.org/10.3765/bls.v25i1.1192

Paradis, C. 1988. On constraints and repair strategies. Linguistic Review 6(1): 71-97.

Paradis, C. and D. LaCharité. 1997. Preservation and minimality in loanword adaptation. Journal of Linguistics 33(3): 379-430. https://doi.org/10.1017/s0022226797006786 
Paradis, C. and D. LaCharité. 2009. English loanwords in Old Quebec French: Fewer bilinguals does not mean a great increase in naive phonetic approximation. Langues et Linguistique 32: 82-117. https://doi.org/10.1017/s0022226707004963

Peperkamp, S. 2005. A psycholinguistic theory of loanword adaptations, In M. Ettlinger, N. Fleischer, and M. Park-Doob (Eds.) Proceedings of the 30th annual meeting of the Berkeley Linguistics Society. Berkeley, CA: Berkeley Linguistics Society. pp. 341-352. https://doi.org/10.3765/bls.v30i1.919

Peperkamp, S., I. Vendelin, and K. Nakamura. 2008. On the perceptual origin of loanword adaptations: Experimental evidence from Japanese. Phonology 28: 129-164. https://doi.org/10.1017/s0952675708001425

R Core Team. 2018. R: A language and environment for statistical computing. R Foundation for Statistical Computing, Vienna, Austria. Available online: https://www.R-project.org/.

Schwade, A.J. 2012. Modality Matters: What Online Adaptations Can Tell Us About Loanword Adaptation. Poster presented at the $43^{\text {rd }}$ North Eastern Linguistic Society conference, 19-21 October 2012, City University of New York. https://doi.org/10.1121/1.4800739

Shinohara, S. 1997. Phonological Analysis of Japanese Adaptations of Foreign Words. Unpublished PhD dissertation, University of Sorbonne-Nouvelle.

Shinohara, S. 2015. Loanword-specific grammar in Japanese adaptations of Korean words and phrases. Journal of East Asian Linguistics 24(2): 149-191. https://doi.org/10.1007/s10831-014$\underline{9129-3}$

Shirai, S. 1999. Gemination in Loans from English to Japanese. Unpublished MA thesis, University of Washington.

Silverman, D. 1992. Multiple scansions in loanword phonology: Evidence from Cantonese. Phonology 9(2): 289-328. https://doi.org/10.1017/s0952675700001627

Smith, J. 2006. Loan phonology is not all perception: Evidence from Japanese loan doublets. In T.J. Vance and K.A. Jones (Eds.) Japanese/Korean Linguistics 14. Stanford, CA: CSLI. pp. $63-74$.

Steriade, D. 2009. The phonology of perceptibility effects: The P-map and its consequences for constraint organization. In K. Hanson and S. Inkelas (Eds.) The nature of the word: Studies in honor of Paul Kiparsky. Cambridge, MA: MIT Press. pp. 151-179. https://doi.org/10.7551/mitpress/9780262083799.003.0007

Stockall, L. and A. Marantz. 2006. A single route, full decomposition model of morphological complexity: MEG evidence. The Mental Lexicon 1(1): 85-123. https://doi.org/10.1075/ $\underline{\mathrm{ml} 1.1 .07 \mathrm{sto}}$

Vendelin, I. and S. Peperkamp. 2006. The influence of orthography on loanword adaptations. Lingua 116(7): 996-1007. https://doi.org/10.1016/j.lingua.2005.07.005 
Vratsanos, A. and M. Kadenge. 2017. Hiatus resolution in Xitsonga. Stellenbosch Papers in Linguistics Plus 52: 175-196. https://doi.org/10.5842/52-0-711

Zuraw, K. 2002. Aggressive reduplication. Phonology 19(3): 395-439. https://doi.org/10. $\underline{1017 / \mathrm{s} 095267570300441 \mathrm{x}}$ 